\title{
Gastrointestinal parasite control during prepuberty improves mammary parenchyma development in Holstein heifers
}

\author{
Adrián F. Perri ${ }^{a, b}$, Miguel E. Mejía ${ }^{a}$, Nicolás Licoffa ${ }^{a}$, Santiago S. Diab ${ }^{c}$, \\ Néstor Formía ${ }^{\mathrm{d}}$, Ana Ornstein ${ }^{\mathrm{a}}$, Damasia Becú-Villalobos ${ }^{\mathrm{a}}$, \\ Isabel M. Lacau-Mengido ${ }^{\mathrm{a}, *}$ \\ a Laboratorio de Regulación Hipofisaria, Instituto de Biología y Medicina Experimental, Vuelta de Obligado 2490, \\ 1428 Ciudad Autónoma de Buenos Aires, Argentina \\ b Facultad de Ciencias Veterinarias, Universidad Nacional del Litoral, Esperanza, Santa Fe, Argentina \\ c Animal Health and Food Safety Laboratory, San Bernardino Branch, University of California, Davis, CA, USA \\ d Escuela Inchausti, Universidad Nacional de La Plata, 25 de mayo, Provincia de Buenos Aires, Argentina
}

\section{A R T I C L E I N F O}

\section{Article history:}

Received 29 July 2013

Received in revised form

11 September 2013

Accepted 13 September 2013

\section{Keywords:}

Gastrointestinal parasites

Puberty

IGF-1

Mammary development

Dairy heifers

\begin{abstract}
A B S T R A C T
Parasitism during development impairs normal growth and delays the onset of puberty through altered hormone profiles, including insulin-like growth factor one (IGF-1). As mammary gland development during prepuberty is strongly dependent on IGF-1, we determined if antiparasitic treatment during this stage of growth improved mammary gland development. One group of Holstein heifers was treated monthly, rotationally with antiparasitic drugs from birth to 70 weeks of age, a second group was untreated. Treated heifer calves had between 56\% and 65\% less EPG counts than untreated ones. Presence of Ostertagia, Cooperia, Haemonchus and Trichostrongylus was demonstrated. Treatment effectively advanced the onset of puberty and increased IGF-1 levels. At 20, 30, 40 and 70 weeks of age biopsies from the mammary gland were taken and histological sections were prepared and stained with hematoxylin-eosin. Pictures were analyzed to compare parenchyma area in relation to total mammary tissue between groups. Mammary samples from treated heifers had higher ratios of parenchyma/total area than untreated ones. As mammary development during prepuberty is crucial for mammary performance during lactation, these results add new evidence to the importance of gastrointestinal parasite control in heifers.
\end{abstract}

(c) 2013 Elsevier B.V. All rights reserved.

\section{Introduction}

We have previously demonstrated that ivermectin treatment during early development in grazing dairy heifers, advanced age at puberty and production onset while decreasing culling rate during the first lactation (Mejía et al., 1999, 2009). Furthermore, parasites in cows during the periparturient period were related to impaired

\footnotetext{
* Corresponding author. Tel.: +54114783 2869; fax: +541147862564. E-mail address: ilacau@ibyme.conicet.gov.ar (I.M. Lacau-Mengido).
}

milk production (Perri et al., 2011). The effects of gastrointestinal parasites, both on development and production itself, were associated with altered profiles of circulating metabolic hormones (Lacau-Mengido et al., 2000, 2009; Díaz-Torga et al., 2001; Perri et al., 2011). Maximal levels of IGF-1 reached during prepuberty were lower in untreated than in ivermectin treated heifers (Lacau-Mengido et al., 2000) and time of prepubertal increase in serum leptin levels was delayed in untreated heifers (Díaz-Torga et al., 2001). In adult lactating cows, diminished milk production in cows with positive nematode egg counting in feces around parturition was associated with decreased prolactin, GH, and IGF-1 levels (Perri et al., 2011). 
On the other hand, mammary gland development during the peripubertal period has been shown to be dependent not only on ovarian control by estradiol stimulus, but also on the IGF-1 system and its local components (Akers et al., 2005). This growth factor strongly stimulates parenchymal cell division during early mammary development and synergizes with estradiol for ductal growth and branching stimulation (Hinck and Silberstein, 2005). Within the gland there is paracrine interaction between stromal and parenchymal cells via growth factors and their receptors which are regulated by extra mammary hormones, such as pituitary, thyroid and ovarian hormones (Forsyth, 1991).

Mammary gland development during the peripubertal period can markedly affect the future milk yield potential (Sejrsen and Purup, 1997). Thus, for scientists seeking to optimize milk production in dairy animals, the peripubertal period has been of increasing interest in recent years. In the present work, considering that parasites lowered IGF-1 during prepuberty and that this hormone is strongly involved in mammary development, we wished to investigate if parasite presence in prepubertal animals can modify mammary development, in addition to their effect on sexual maturity. Because ivermectin resistance has already been demonstrated in Argentina (Anziani et al., 2001), an alternative rotational drug protocol was used for parasite control and the effect on puberty onset and IGF-1 levels was also evaluated.

\section{Materials and methods}

The experiment was conducted at the dairy farm of the Experimental School of Inchausti, 25 de mayo, Province of Buenos Aires, Argentina (35 $36^{\prime}$ S, 60 $32^{\prime} \mathrm{W}$ ). Forty female Holstein calves were randomly assigned, at birth, to an untreated control group (C) or to the treated group ( $\mathrm{T}$ ) which received, from birth onward, monthly anthelminthic treatment rotating different drugs in order to minimize parasite burden, and mitigate drug resistance. The following drugs were used: ivermectin (I, $0.63 \mathrm{mg} / \mathrm{kg}$, Ivomec Gold $^{\circledR}$, Merial), fenbendazole (F, $7.5 \mathrm{mg} / \mathrm{kg}$, Axilur $\left.^{\circledR}, \mathrm{MSD}\right)$ and levamisole (L, $10 \mathrm{mg} / \mathrm{kg}$, Ripercol $\mathrm{L}^{\circledR}$, Pfizer SRL). The sequence was L, F, F, F, I; F, F, F, L, L, I, L, L, F, F, F, I, starting in August (Winter). The schedule was reasoned as follows: ivermectin was used against inhibited Ostertagia (in December) and a dose in Winter to rotate with levamisole and protect the animals against mange. Levamisole was used in the Winter months when there is no inhibition of Ostertagia. Fenbendazole was used in Spring and Summer to rotate with the other drugs.

All the heifers were raised together with the replacement herd of the dairy farm, outdoors on infected pastures (always assigned to rearing calves) and supplemented with milk and/or concentrate or corn or silage according to age. At birth, calves were placed in individual cages, directly on the pastures, which were moved when the floor turned dirty or humid. They stayed in cages during the first 2 months of life, and during this time they were fed 21 of warm milk twice a day and had ad libitum access to balanced supplement. Then, they were included in the grazing herd and grazed on alfalfa and (or) ryegrass pastures, in a rotational grazing system (stocking density: 8 animals/Ha), with ad libitum access to the supplement. At $160 \mathrm{~kg}$ of BW the supplement was changed to corn ( $2 \mathrm{~kg} /$ animal day) and the stocking density was reduced to 2 animals/Ha.

At 20, 30, 40 and 70 weeks of age jugular blood and fecal samples were individually obtained from all the heifers in the study, for serum IGF-1 determination by RIA and nematode egg counting in feces. At the same time, mammary biopsies were taken from 6 heifers in each treatment group (Licoff et al., 2009). Heifers were sedated with acepromazine $1 \%(0.15 \mathrm{mg} / \mathrm{kg}$, Holliday Scott S.A.) and immobilized in the supine position. The udder was cleaned with soap and water, rinsed and disinfected with an iodine solution. The biopsy was taken two centimeters away from the nipple in the rear right quarter under local anesthesia (5 ml lidocaine 2\% sc). Each biopsy (at 20, 30, 40 and 70 weeks) was taken in a different place, rotating in clockwise sense from frontal direction, to avoid previous cicatricial tissue. A Tru-Core ${ }^{\mathrm{TM}}$ I fully automatic biopsy gun provided with a Tru-Core ${ }^{\circledR} 14$ G X $20 \mathrm{~cm}$ needle (Medical Device Technologies, Inc.) was used. The needle directly pierced the skin, and a gland sample of $3 \mathrm{~mm}$ wide per $1 \mathrm{~cm}$ long was obtained with minimal lesion.

Additional weekly bleeding was performed in all the heifers between 28 and 48 weeks of age for progesterone and time of puberty onset determination. When progesterone exceeded $1 \mathrm{ng} / \mathrm{ml}$, heifers were considered to be puberal (Mejía et al., 1999).

\subsection{Sample treatments}

Fecal samples were maintained at $4{ }^{\circ} \mathrm{C}$ until examination. Blood samples were centrifuged and sera stored at $-20^{\circ} \mathrm{C}$ for hormone determination. Mammary gland samples were immediately fixed in buffered formaldehyde $4 \%$, for histological studies.

\subsection{Nematode egg counting}

Nematode eggs were counted in fresh fecal samples by the Mc. Master method adapted by INTA, with a sensitivity of 10 eggs and expressed as number of eggs per gram of sample (EPG) (Mejía et al., 1999). Cultures were performed in pooled samples, at each biopsial date, to identify the genera of the larvae. Those were Cooperia, Ostertagia, Trichostrongylus and Haemonchus.

\subsection{Hormone determinations}

The IGF-1 RIA was performed after acid-ethanol extraction as described in Lacau-Mengido et al. (2000). The IGF-1 antibody (UB2-495) of the NIDDK was used. Intra-assay coefficient of variation was $8 \%$, and minimum detectable concentration was $2.5 \mathrm{ng} / \mathrm{ml}$. Progesterone was determined with a RIA using antibody provided by G. D. Niswender, after double extraction with hexane. Labeled hormone (progesterone $[1,2,6,73 \mathrm{H}(\mathrm{N})]$ ) was purchased from Dupont NEN (Boston, MA). Assay sensitivity was $50 \mathrm{pg}$, and intra- and interassay coefficients of variation were less than $8 \%$ and $12 \%$, respectively. 


\subsection{Histological procedures}

Samples were fixed in buffered formaldehyde for $8 \mathrm{~h}$ at room temperature, then rinsed thoroughly with tap water and phospho-saline buffer (PBS, 0.05 M pH 7.5), subjected to dehydration in increasing concentrations of ethanol, washed in xylol and fixed in paraffin. Serial sections of $5 \mu \mathrm{m}$ wide were cut with a manual microtome and mounted on glass slides previously coated with 3-aminopropyltriethoxysilane (Sigma-Aldrich, St. Louis, MO). Slides were then deparaffinized, rehydrated and stained with hematoxylin-eosin (Dallard et al., 2007).

\subsection{Image analysis}

Pictures from every histological section of all the biopsies were obtained by means of a video color camera (CCD Moticam 2000, Mikron Instrument Inc., California, USA) mounted on an optical microscope (Olympus CX31, Olympus Co., Japan) with a $40 \times$ objective. Images were digitalized and saved under TIFF format with a $1200 \times 1600$ pixels definition and 24 color bits. Each field represented a tissue area of $0.032 \mathrm{~mm}^{2}$ and each pixel $0.13 \mu \mathrm{m}$. ImagePro Plus 3.0.1 1 (Media Cybernetics, Silver Spring, MA, USA) was used for image analyses. Between 30 and 40 pictures were taken for each biopsy in different portions of the sample. Parenchyma was stained in blue-violet because of the high number of nuclei (with acid components) due to tight epithelial cells. Stroma was slightly stained in pink or remained unstained as it is composed by collagen fibers embedded in a matrix and big lipid cells. In each picture parenchymal area was manually delineated and both parenchymal and total areas were quantified with the Image-Pro Plus software. The proportion of parenchyma over total area was expressed as a percentage.

\subsection{Statistical analysis}

Treatment effect on EPG and IGF-1 values was analyzed by two-way ANOVA for repeated samples (treatment $\times$ age), with previous transforming EPG values for normalization of the data using arcsin function. Kaplan-Meier survival analysis was performed for pubertal comparison, setting puberty as the event and age as the variable. Posterior log-rank test was used to compare both survival curves. Non-parametric tests were used to compare percentages of parenchymal area in the pictures: Friedman test was used to determine treatment and time effects and Mann-Whitney test was used for the effect of treatment within ages.

\section{Results}

EPG counts in feces decreased with age $(P=0.027)$ and were higher in $C$ than $T$ heifers $(P=0.020)$. IGF-1 levels increased with age $(P=0.003)$ and were higher in $T$ than $C$ heifers $(P=0.042)$ (Fig. $1 \mathrm{~A}$ and $\mathrm{B})$. Range of EPG levels, percentage of mean EPG decrease in $T$ with respect to $C$ heifers and nematode genera present at each studied age are shown in Table 1.
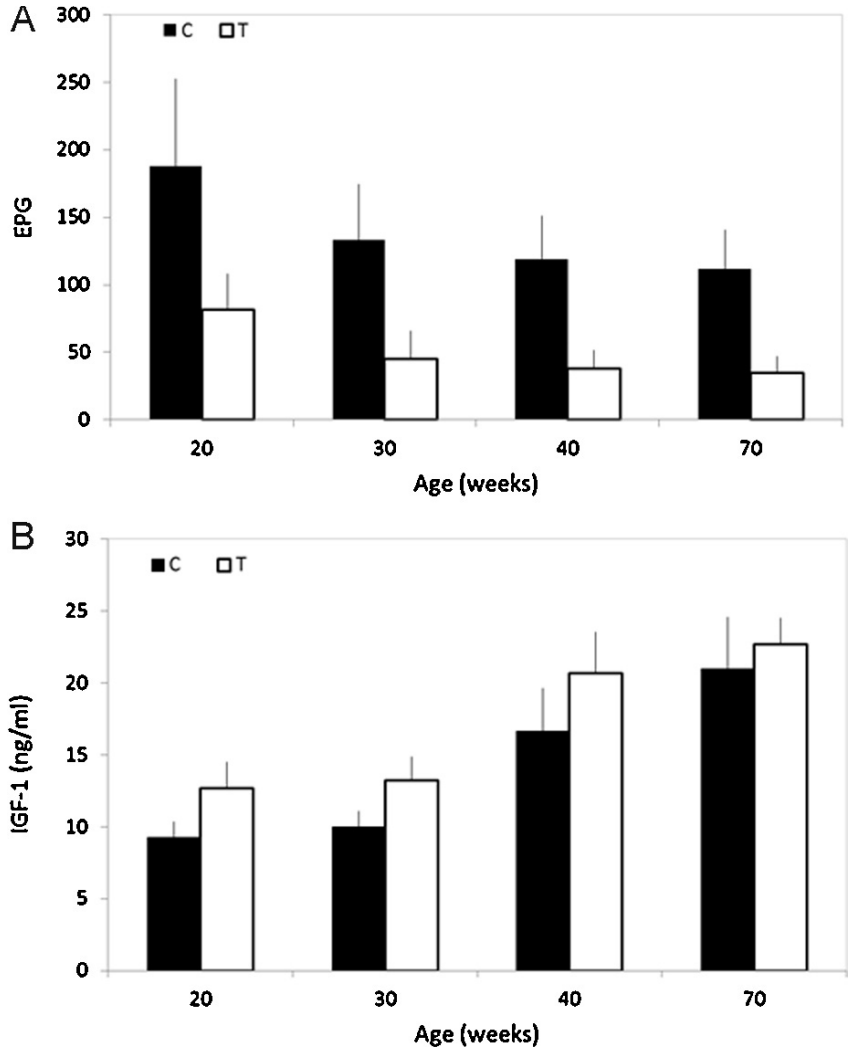

Fig. 1. Eggs of nematodes in feces (A) and IGF-1 in serum (B) of antiparasitic treated $(\mathrm{T}=$ white bars $)$ and untreated $(\mathrm{C}=$ black bars $)$ heifers at 20 , 3040 and 70 weeks of age when biopsies were taken $(T \neq C, P<0.05$, for both parameters, see text).

Treated heifers reached puberty before untreated ones $(P=0.018)$ as shown by survival curves in Fig. 2 . Mean age at puberty was $33.8 \pm 0.7$ weeks for the treated group and $38.1 \pm 1.6$ for the untreated one, whereas the global mean of the entire sample was $35.9 \pm 0.9$ week.

Sequential representative pictures of whole biopsy slices from one control and one treated heifer at all the ages studied are shown in Fig. 3. Mammary samples from treated heifers had higher parenchymal/total area ratio than control ones $(P=0.036)$; no effect of age was evidenced for treated $(P=0.12)$ or untreated $(P=0.36)$ heifers (Fig. 4$)$.

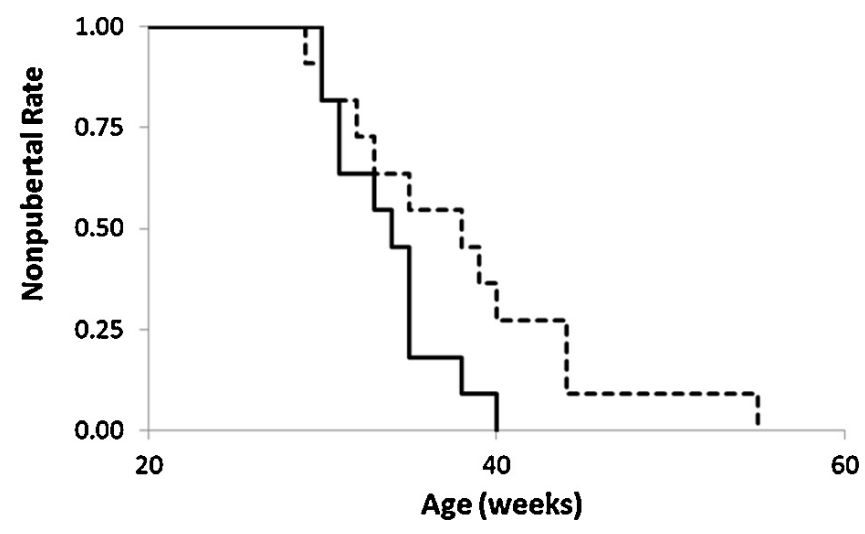

Fig. 2. Survival Kaplan-Meier curves for puberty onset of antiparasitic treated (full line) and untreated (hatched line) heifers. Puberty was set as event and week of age as time variable (log-rank test, $P<0.02$ ). 
Table 1

Range of EPG levels in feces of control and treated heifers, percent of reduction in mean EPG levels in treated (EPG(T)) versus untreated (EPG(C)) heifers and nematode genera present in pooled feces, at 20,30, 40 and 70 weeks of age $(\mathrm{Co}=$ Cooperia, $\mathrm{H}=$ Haemonchus, $\mathrm{O}=$ Ostertagia, $\mathrm{T}=$ Trichostrongylus $)$.

\begin{tabular}{lllll}
\hline & & 20 weeks & 30 weeks & 40 weeks \\
\hline Range of EPG & C & $0-1100$ & $0-640$ & $0-440$ \\
& T & $0-440$ & $0-280$ & $0-220$ \\
(EPG $(\mathrm{C})-\mathrm{EPG}(\mathrm{T})) \times 100 / \mathrm{EPG}(\mathrm{C})$ & & 57 & 66 & 68 \\
Genera present & & Co-H-O-T & Co-H-O-T & Co-H-O \\
\hline
\end{tabular}

Age

20

30

40

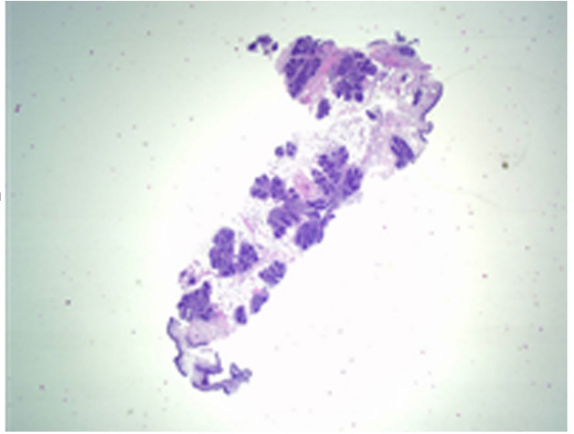

70

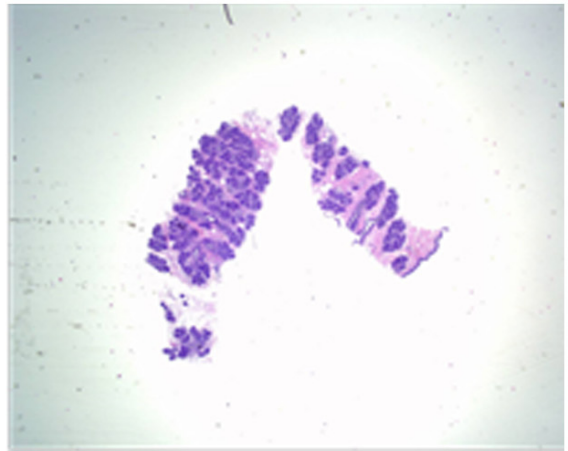

C
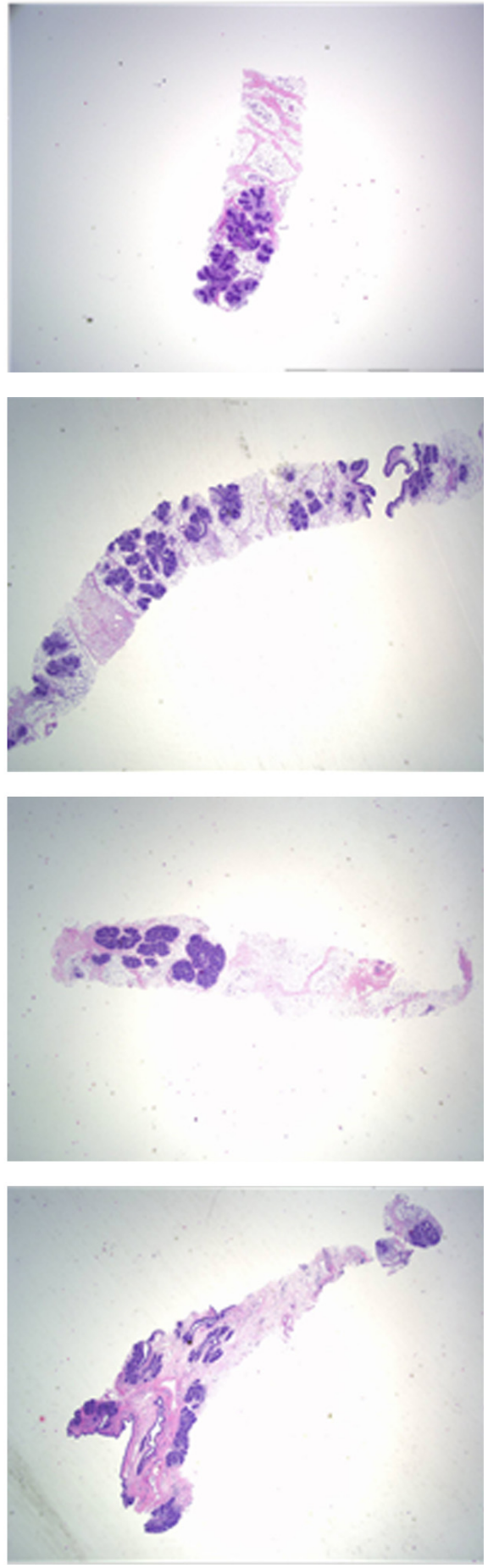

Fig. 3. Pictures of slides from mammary biopsies stained with hematoxylin-eosin $(200 \times)$ showing parenchyma in blue-violet and stroma in white-pink, of one antiparasitic treated ( $\mathrm{T}$, right pictures) and one untreated (C, left pictures) heifers, at 20, 30, 40 and 70 weeks of age. 


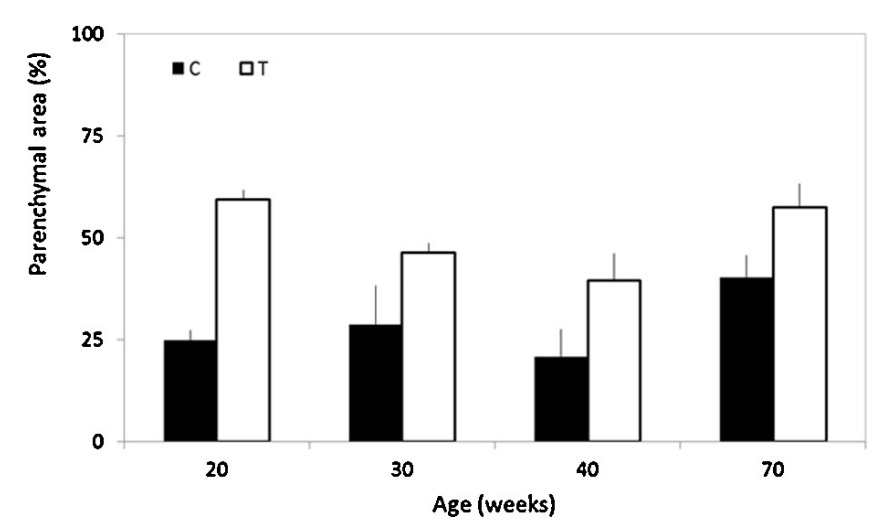

Fig. 4. Percent of parenchyma over total area in biopsies of antiparasitic treated (T, white bars) and untreated (C, black bars) heifers at 20, 30, 40 and 70 weeks of age $(C \neq T, P<0.05)$.

\section{Discussion}

Parasite infection is known to impair general growth, but its effect on mammary development has not been investigated. In the present work we show that antiparasitic treatment correlated with increased mammary parenchyma development in Holstein heifers.

Antiparasitic treated heifers had lower EPG levels than untreated age-matched ones, as expected. Results differed from our previous experiments (Mejía et al., 1999) as antiparasitic treatment did not totally suppress egg counts. This is due to the development of multiple drug resistance by the parasites in Argentina (Mejía et al., 2003), in addition to ivermectin resistance (Fiel et al., 2000; Anziani et al., 2001). However, differences observed in EPG were sufficient to alter IGF-1 levels, and this hormone was consistently lower in untreated compared to treated heifers, similarly to results obtained with ivermectin alone in the works performed before the appearance of the resistance to this drug in this farm (Lacau-Mengido et al., 2000; DíazTorga et al., 2001).

Furthermore, differences in parasite burden between groups were sufficient to delay puberty onset as well. The mean delay of four weeks was similar to that previously reported (Lacau-Mengido et al., 2000), in spite of differences in parasite burden achieved and variation in climate and grass availability between studies. In the previous experiment the four weeks delay in puberty onset resulted in a four months delay in the achievement of pregnancy (parameter which was not measured in the present study) retarding the onset of productive life more than that of puberty (Mejía et al., 2009).

Taking into account differences encountered in IGF-1 and puberty onset we compared mammary development features between the two groups of heifers. Ages chosen for mammary biopsies differed with respect to heifer sexual maturity in each group. At 20 weeks of age no heifers were pubertal. At 30 weeks of age, the transition to puberty was shown by a small number of heifers cycling in each group ( $18 \%$ and $9 \%$ for treated and untreated groups, respectively). At 40 weeks, puberty was evident in all the heifers in the treated group and $73 \%$ of the untreated group. At 70 weeks of age, all the heifers in both groups were already mature.
Mammary development during peripuberty consists in growth and branching of ducts of epithelial cells, advancing from the nipple to the interior of the gland (Berry et al., 2003). Those ducts end in buttons of multiple cells with active division. The ensemble of ducts and cellular buttons constitute the mammary parenchyma which will become the milk secreting tissue. The ducts grow within the fat pad which is a mesenchymal stroma with high proportion of adipocytes. As the gland matures, a higher proportion of parenchyma is present within the gland (Sejrsen et al., 1999; Hovey and Trott, 2004). This branching and development of the parenchyma was captured in the histological slides performed in this work and is shown by sequential pictures of two heifers, as an example, in Fig. 3. Relative development evaluated by parenchyma/total area ratio reflects parenchymal growth within the gland. Significantly higher values were evidenced in the treated group compared to the untreated heifers, showing a higher maturity of the gland when gastrointestinal parasites are controlled. However, no age related increase in rates could be demonstrated within each group. This can be simply related to the small number of heifers sampled per group. But, a high parenchyma/total area encountered in the treated group at 20 weeks of age may also mask the developing effect, though biopsies were taken always at the same distance from the nipple, in a radiate manner. As it has been demonstrated that parenchymal cells from the peripheral zone of the gland have higher proliferative response to growth factors than those from the medial area when tested in vitro (Ellis et al., 2000), it could be inferred that only biopsies from 20 weeks were taken in the peripheral area (because of a smaller gland), whereas later biopsies fell in the medial zone with lower division rate.

Increased circulating IGF-1 levels observed in the treated heifers in comparison to untreated ones, may account for the difference in parenchyma/total area reported. The effect of gastrointestinal parasite presence on this growth factor concentration was already discussed in previous publications (Mejía et al., 1999, 2009; LacauMengido et al., 2000; Perri et al., 2011), and it basically depends on parasite effect on host nutrition status. The pathogenesis of gastrointestinal nematode infections is associated with inappetence and increased loss of proteins into the gastrointestinal tract which drives the animal to an undernutrition status (Forbes et al., 2007; Symons, 1985; Holmes, 1987). In this regard, undernutrition in prepubertal sows has been shown to reduce the parenchymal proportion in their mammary glands (Farmer et al., 2004). In heifers similar results were found, food restriction affected mammogenesis, reducing parenchymal growth (Capuco et al., 1995; Dobos et al., 2000; Farmer et al., 2004).

Ductal morphogenesis is conducted by an orchestred tuning of pituitary and ovarian hormones (McNally and Martin, 2011). Both IGF-1 and estradiol are the main promoters of ductal growth during peripuberty and both synergize (Kleinberg and Barcellos-Hoff, 2011). The effects of those hormones are also modulated by internal mammary factors (Akers, 2006).

The present results demonstrate that antiparasitic treatment in naturally infected heifers effectively enhances 
parenchymal growth during peripuberty, in addition to advancing the onset of puberty. Both effects are probably related to increased serum IGF-1 concentration during development. As parenchymal size is crucial for lactation performance in adulthood, reduced growth during peripubertal mammogenesis could affect future productive capacity of the gland.

\section{Acknowledgements}

This work was supported by ANPCYT and CONICET, Argentina.

\section{References}

Akers, R.M., 2006. Major advances associated with hormone and growth factor regulation of mammary growth and lactation in dairy cows. J. Dairy Sci. 89, 1222-1234.

Akers, R.M., Ellis, S.E., Berry, S.D., 2005. Ovarian and IGF-I axis control of mammary development in prepubertal heifers. Domest. Anim. Endocrinol. 29, 259-267.

Anziani, O.S., Zimmermann, G., Guglielmone, A.A., Vazquez, R., Suarez, V., 2001. Avermectin resistance in Cooperia pectinata in cattle in Argentina. Vet. Rec. 149, 58-59.

Berry, S.D., Howard, R.D., Jobst, P.M., Jiang, H., Akers, R.M., 2003. Interactions between the ovary and the local IGF-I axis modulate mammary development in prepubertal heifers. J. Endocrinol. 177, 295-304.

Capuco, Smith, A.V., Waldo, J.J., Rexroad, D.R., C.E.Jr., 1995. Influence of prepubertal dietary regimen on mammary growth of Holstein heifers. J. Dairy Sci. 78, 2709-2725.

Dallard, B.E. Ruffino, V., Heffel, S., Calvinho, LF., 2007. Effect of a biological response modifier on expression of growth factors and cellular proliferation at drying off. J. Dairy Sci. 90, 2229-2240.

Díaz-Torga, G.S., Mejía, M.E., González-Iglesias, A., Formía, N., BecúVillalobos, D., Lacau-Mengido, I.M., 2001. Metabolic cues for puberty onset in free grazing Holstein heifers naturally infected with nematodes. Theriogenology 56, 111-122.

Dobos, R.C., Nandra, K.S., Riley, K., Fulkerson, W.J., Lean, I.J., Kellaway, R.C., 2000. The effect of dietary protein level during the pre-pubertal period of growth on mammary gland development and subsequent milk production in Friesian heifers. Livestock Production Sci. 63, 235-243.

Ellis, S., Purup, S., Sejrsen, K., Akers, R.M., 2000. Growth and morphogenesis of epithelial cell organoids from peripheral and medial mammary parenchyma of prepubertal heifers. J. Dairy Sci. 83, 952-961.

Farmer, C., Petitclerc, D., Sorensen, M.T., Vignola, M., Dourmad, J.Y., 2004. Impacts of dietary protein level and feed restriction during prepuberty on mammogenesis in gilts. J. Anim. Sci. 82, 2343-2351.

Fiel, C., Saumell, C., Steffan, P.E., Rodríguez, E., Salaberry, G., 2000. Resistencia de los nematodos Trichostrongylideos-Cooperia y Trichostrongylus - a tratamientos con avermectinas en bovinos de la Pampa Húmeda. Argentina. Rev. Med. Vet. (Arg.) 81, 310-315.
Forbes, A.B., Huckle, C.A., Gibb, M.J., 2007. Evaluation of the effect of eprinomectin in young dairy heifers sub-clinically infected with gastrointestinal nematodes on grazing behaviour and diet selection. Vet. Parasitol. 150, 321-332.

Forsyth, I.A., 1991. The mammary gland. Baillieres Clin. Endocrinol. Metab. 5, 809-832.

Hinck, L., Silberstein, G.B., 2005. Key stages in mammary gland development: the mammary end bud as a motile organ. Breast Cancer Res. 7 245-251.

Holmes, P.H., 1987. Pathophysiology of nematode infections. Int. J. Parasitol. 17, 443-451.

Hovey, R.C., Trott, J.F., 2004. Morphogenesis of mammary gland development. Adv. Exp. Med. Biol. 554, 219-228.

Kleinberg, D.L., Barcellos-Hoff, M.H., 2011. The pivotal role of insulin-like growth factor I in normal mammary development. Endocrinol. Metab. Clin. North Am. 40, 461-471, vii.

Lacau-Mengido, I.M., Mejia, M.E., Becu-Villalobos, D., 2009. Gastrointestinal nematode effects on grazing dairy herds during development and its impact on production. In: Di Alberto, P., Costa, C. (Eds.), New Research on Livestock Science and Dairy Farming. Nova Science Publishers, Inc., New York, pp. 141-164.

Lacau-Mengido, I.M., Mejía, M.E., Díaz-Torga, G.S., González-Iglesias, A. Formía, N., Libertun, C., Becú-Villalobos, D., 2000. Endocrine studies in ivermectin-treated heifers from birth to puberty. J. Anim. Sci. 78, $817-824$

Licoff, N., Diab, S., Perri, A.F., Mejia, M.E., Formía, N., Becu-Villalobos, D. Lacau-Mengido, I.M., 2009. Mammary biopsies in prepubertal heifers. Histological studies of the developmental gland. Effect of anthelmintic treatment. Biocell 33, A40.

McNally, S., Martin, F., 2011. Molecular regulators of pubertal mammary gland development. Ann. Med. 43, 212-234.

Mejía, M.E., Fernández-Igartúa, B.M., Schmidt, E.E., Cabaret, J., 2003. Multispecies and multiple anthelmintic resistance on cattle nematodes in a farm in Argentina: the beginning of high resistance? Vet. Res. 34 461-467.

Mejía, M.E., González-Iglesias, A., Díaz-Torga, G.S., Villafañe, P., Formía, N., Libertun, C., Becú-Villalobos, D., Lacau-Mengido, I.M., 1999. Effects of continuous ivermectin treatment from birth to puberty on growth and reproduction in dairy heifers. J. Anim. Sci. 77, 1329-1334.

Mejía, M.E., Perri, A.F., Miglierina, M.M., Formía, N., Becú-Villalobos, D., Lacau-Mengido, I.M., 2009. Effect of anthelmintics on reproductive performance and first lactation culling rate in Holstein heifers. Vet. Rec. 165, 143-146.

Perri, A.F., Mejia, M.E., Licoff, N., Lazaro, L., Miglierina, M., Ornstein, A., Becu-Villalobos, D., Lacau-Mengido, I.M., 2011. Gastrointestinal parasites presence during the peripartum decreases total milk production in grazing dairy Holstein cows. Vet. Parasitol. 178, 311-318.

Sejrsen, K., Purup, S., 1997. Influence of prepubertal feeding level on milk yield potential of dairy heifers: a review. J. Anim. Sci. 75, 828-835.

Sejrsen, K., Purup, S., Vestergaard, M., Weber, M.S., Knight, C.H., 1999. Growth hormone and mammary development. Domest. Anim. Endocrinol. 17, 117-129.

Symons, L., 1985. Anorexia: occurrence, pathophysiology, and possible causes in parasitic infections. Adv. Parasitol. 24, 103-133. 